\title{
SS-067 ジェンダーの視点から考えるキャリア形成と課題
}

\author{
企画代表者，指定討論者，司会者：縜坂 英子 (駿河台大学) \\ 企画者: 伊藤 裕子 (文京学院大学) \\ 話題提供者：小野寺敦子 (目白大学) \\ 話題提供者: 渡邊 寛 (筑波大学) \\ 話題提供者：滑田 明暢（静岡大学大学教育センター） \\ 指定討論者: 松並 知子 (武庫川女子大学)
}

ニューエコノミーのもと安倍政権は女性の活躍政策を謳ったが，女性のライフワークバランスが十分 に実現されているとは言い難い。2017年の内閣府の調査よれば，男性の非正規雇用率が $21.9 \%$ あるの に対して女性は $55.5 \%$ を占め, 女性の雇用は男性社会の調整手段として機能し, 女性が安価に消費され ながら社会から周縁化されている。家族の扶養や社会の利益に結びつくような男性性を体現できない男 性もまた，女性と同じく社会から周縁化され，男女格差だけでなく男性内格差が生み出されている。ま た男性は全体として雇用や収入で女性よりも優位な位置にありながら，内閣府（2014）の調査では男性 の主観的な幸福感は女性よりも低いと報告されている。本シンポジウムでは女性のキャリア形成や生き づらさは，女性問題であると同時に男性問題でもあるという観点に立ち，日本社会におけるキャリアの 現況と課題, 性役割の変化について議論を深めていく。

\section{第2日 9 月12日(木) $15: 40 \sim 17: 40$}

A 棟 2 階／第14会場 AN222

\section{SS-068＼cjkstart社会生活における Negativity のポジティブサイド}

\author{
企画代表者, 話題提供者: 友野 隆成（宮城学院女子大学） \\ 企画者, 話題提供者: 上原 俊介 (鈴鹿医療科学大学) \\ 話題提供者: 手塚 洋介 (大阪体育大学) \\ 指定討論者: 福野 光輝 (東北学院大学) \\ 司会者: 福島 治 (新潟大学)
}

ネガティブなものは悪く，ポジティブなものほど良い，という人々の勧善懲悪的な態度を反映するか のように, 幸福追求を指南する書籍やセミナーが世間に数多く存在している。だが, Negativity が悪者 というのは真実であろうか。近年,「The Positive Side of Negative Emotions」といった書籍が刊行さ れ，ネガティブ事象のポジティブな側面をあらためて見直す動きがみられている。そこで本シンポジウ ムでは, 社会生活に扔ける様々なネガティブ事象のポジティブな側面について, 感情・社会・パーソナ リティの各領域から議論を深めることを試みる。具体的には, アスリートのパフォーマンスに関する研 究・怒り表出の関係促進効果に関する研究・瞹昧さ耐性とストレスイベントに関する研究から, 各々ネ ガティブな現象にポジティブな側面が観察されるか検討する。そして, Negativity についての理解をさ らに深める機会としたい。 